\begin{tabular}{l} 
SCIENCE \& TECHNOLOGY \\
Journal homepage: http://www.pertanika.upm.edu.my/ \\
\hline PERTANIKA
\end{tabular}

\title{
Diffusion and Osmotic Permeability of Ion Exchange Membrane MK-40 Using Sodium Chloride Solution
}

\author{
Mohammed Qader Gubari ${ }^{1,2}$, Haider Mohammed Zwain ${ }^{3 *}$ and \\ Nadezda Vyacheslavovna Alekseeva ${ }^{2}$ \\ ${ }^{1}$ Department of Fuel and Energy Engineering Technologies, Technical College Kirkuk, \\ Northern Technical University, Mosul, Iraq \\ ${ }^{2}$ Department of Technological Processes, Devices and Technosphere Safety, Tambov State Technical University, \\ Tambov, Russia \\ ${ }^{3}$ College of Water Resources Engineering, Al-Qasim Green University, 51013 Al-Qasim Province, Babylon, Iraq
}

\begin{abstract}
Cation exchange membrane (MK-40) is a commercial membrane with a fixed group that is an important part of the electrodialysis (ED) process. Sodium chloride $(\mathrm{NaCl})$ diffusion and osmotic permeability for MK-40 was studied. A cell containing two compartments was used to analyse the properties of the MK-40 membrane fixed between them. Furthermore, the influence of temperature, $\mathrm{NaCl}$ concentration, and operating time on $\mathrm{MK}-40$ properties was investigated. The results showed that the highest diffusion permeability coefficient of $\mathrm{NaCl}$ was $7.37 \times 10^{-9}\left(\mathrm{~m}^{2} / \mathrm{s}\right)$, and the maximum osmotic permeability coefficient of distilled water was $43.8 \times 10^{-9}\left(\mathrm{~m}^{2} / \mathrm{s}\right)$ at $\mathrm{NaCl}$ solution concentration of $0.1 \mathrm{M}$ and $50^{\circ} \mathrm{C}$. Generally, the permeability was constant beyond $60 \mathrm{~min}$ of operational time. Additionally, the minimum diffusion permeability coefficients of the MK-40 membrane fell by about $22 \%$ over time when the concentration of $\mathrm{NaCl}$ solution was $1 \mathrm{M}$ at $25^{\circ} \mathrm{C}$. To conclude, membrane properties in the ED process

ARTICLE INFO

Article history:

Received: 29 March 2021

Accepted: 05 July 2021

Published: 08 October 2021

DOI: https://doi.org/10.47836/pjst.29.4.14

E-mail addresses:

mohammedqader1983@gmail.com (Mohammed Qader Gubari)

haider.zwain@wrec.uoqasim.edu.iq (Haider Mohammed Zwain)

alexejewa.nadja@gmail.com (Nadezda Vyacheslavovna

Alekseeva)

* Corresponding author depend on the two electrodes (a cathode and an anode), without the diffusion of salts particles. Meanwhile, the most important properties of cation exchange membranes (CEMs) used in electrodialysis are increased membrane efficiency when water and salts transport decrease through CEMs, which leads to a decrease in energy consumption. Thus, the MK-40 membrane showed a good
\end{abstract}


properties due to its low diffusion permeability for concentrated $\mathrm{NaCl}$ solution at elevated temperatures and minimum reduction in diffusion permeability of concentrated $\mathrm{NaCl}$ solution over time.

Keywords: Cation exchange membrane (MK-40), diffusion permeability, electrical conductivity, osmotic permeability, sodium chloride

\section{INTRODUCTION}

Industrial application of ion exchange membranes (IEMs) started with saltwater desalination, and membranes are widely used in many fields such as drinking water treatment, treated wastewater treatment, amino acid demineralisation, sugar liquor demineralisation, whey demineralisation, and purification of organic matter. Saline water desalination is the most appropriate and commonly used fundamental technology of these applications (Tanaka, 2011). Recent years have seen extensive use of IEMs in processes such as electrodialysis (ED), diffusion dialysis, dialysis of Donnan, and capacitive deionisation (Chaabouni et al., 2015). Owing to their chemical stability, water transport properties and desirable ion, IEMs have recently attracted considerable interest in membrane-based technologies (Geise et al., 2014a).

MK-40 is one of the heterogeneous cation ion exchange membranes in the form of a flat sheet (Vasil'eva et al., 2013). MK-40 composites are developed based on KU-2 cation exchange resins (a matrix of polystyrene (PS) cross-linked with divinylbenzene (DVB) and fixed groups), polyethylene and nylon (Melnikov et al., 2018). MK-40 rejects an ion with the same charge (co-ions) and enables the passage of oppositely charged ion (counter-ions) (Geise et al., 2014b). The main application of MK-40 in processes of water desalination (Andreeva et al., 2020). On the other hand, IEMs are considered a key component of electrodialysis (ED) systems. Their contribution to the process's overall cost may be as large as 40 to $50 \%$ (Mikhaylin \& Bazinet, 2016). Therefore, the application of technologies utilizing IEMs is typically defined by the transport properties and costs of IEMs.

IEMs are mainly affected by several parameters: temperature, solution concentration, electrical conductivity, and flux time. Temperature is one of the most important characteristics that can affect the electrical conductivity and fluid flow, and the characteristics of IEMs. Therefore, it is very important to optimise the temperature (Karimi \& Ghassemi, 2016). For instance, Guesmi et al. (2010) reported that different temperatures $\left(10,25\right.$, and $\left.40^{\circ} \mathrm{C}\right)$ had significantly affected the ion exchange equilibrium of the system with CMX cation exchange membrane involving monovalent and divalent ions. Nevertheless, the salt concentration also influences the diffusion permeability, conductivity, and ion transport numbers (Sarapulova et al., 2019). For example, Geise et al. (2013) found that when the salt concentration increased from 0.58 to $58 \mathrm{~g} / \mathrm{L}$, the permeability of sodium chloride decreased by $16 \%$ in uncharged hydrogel and increased by more than $10 \%$ in charged polymers. 
In this regard, diffusion and osmotic permeability are key indicators for IEMs characteristics. It can be measured by two-compartments cells used for calculating diffusion and osmotic permeability coefficients. The values of diffusion and osmosis depend on the size of the system, and on the concentration profiles of dilute and concentrate solutions, which are set by the application of the ED system (Chehayeb et al., 2019). Many methods have been used to determine the effect of solution properties on membrane diffusion permeability, such as solution concentration, temperature and flux time. For example, Kingsbury et al. (2018) studied the permeability of water and salt simultaneously using a two-chamber cell. One-half of the cells consisted of a $\mathrm{NaCl}$ solution, while the other half consisted of distilled water. In addition, a concentrated $\mathrm{NaCl}$ solution was selected to optimise the osmosis rate and promote water transport measurements. Furthermore, the non-flow two-chamber cell was used by Melnikov et al. (2018) to analyse the permeability of the diffusion. Half of the cell consisted of salt or acid, while the second half consisted of distilled water.

From the literature, permeation of co-ions of $\mathrm{NaCl}$ via diffusion and water by osmosis is a non-ideal movement that cannot be regulated by electrical fields and thus decreases the performance of electrochemical processes. Consequently, limiting non-ideal transport of water and salt (osmosis and salt diffusion) is a key objective to study the effect of some parameters on CEM (MK-40) performance (Gubari et al., In Press). To date, there are a few researchers who have evaluated the effect of discharged feed solutions and different distilled water temperatures on diffusion and osmatic permeability of CEMs in the ED process to verify the effectiveness of membrane separation. Therefore, this study aims to investigate the diffusion and osmotic permeability of MK-40 membrane, employing two compartments cell, using $\mathrm{NaCl}$ solution and distilled water, at different salt concentrations $(0.1,0.5$ and $1 \mathrm{M})$ and different distilled water temperatures $\left(25\right.$ and $\left.50^{\circ} \mathrm{C}\right)$.

\section{MATERIALS AND METHODS}

\section{Membranes and Reagents}

The MK-40 membrane is effective for small-scale water desalination due to its low cost and long lifetime (Gubari et al., 2021). The copolymerisation of polystyrene obtained by Ion-exchange materials in the MK-40 membrane with divinylbenzene. "Shchekinoazot" (Russian) manufactured this membrane in the form of flat sheets (Vasil'eva et al., 2013). MK-40 membrane pore size distribution indicates two maxes, the first one approximately $10 \mathrm{~nm}$ and corresponding to micro and mesoporous, and the second relates to macropores around $1000 \mathrm{~nm}$ in sizes. The pores of the membrane MK-40 are positioned within the sulfonated ion-exchange particles (MK-40). The second pores type is the spaces in a membrane between various particles (Nikonenko et al., 2019). Table 1 collects the main features of commercial MK-40 membranes (Pismenskaya et al., 2012). In this study, 
distilled water (electric conductivity of $\left.4.5 \mu \mathrm{S} \mathrm{cm}^{-1} ; \mathrm{pH}=5.5 ; 25^{\circ} \mathrm{C}\right)$ and $\mathrm{NaCl}(\geq 99.7 \%$ purity) at different concentrations were used.

Table 1

Properties of commercial MK-40 membrane

\begin{tabular}{lc}
\hline Membrane & Cation exchange (MK-40) \\
\hline Ion exchange groups, bulk & $-\mathrm{SO}_{3}^{-}$ \\
Idem, surface & $-\mathrm{SO}_{3}^{-}$ \\
Thickness, $\mu \mathrm{m}$ & $480 \pm 10$ \\
Ion exchange capacity, $\mathrm{mM} \mathrm{cm}{ }^{-3}$ wet & $1.7 \pm 0.1$ \\
Ion exchange material surface fraction of, $\%$ & $22 \pm 3$ \\
Contact angle, degrees & $55 \pm 3$ \\
Particular conductivity in solution $0.5 \mathrm{M} \mathrm{NaCl}, \mathrm{mS}^{-{ }^{-1}}-1$ & $7.7 \pm 0.3$ \\
Diffusion permeability, $10^{-8} \mathrm{~cm}^{2} . \mathrm{s}^{-1}$ & $6.7 \pm 0.4$ \\
\hline
\end{tabular}

\section{Salt and Water Penetration Measurements}

The coefficients of salt diffusion were determined from the calculation of the self-diffusion, taking into account the diluting effects of osmosis in the gradient of salt concentration. In other word, the flow of water from the distilled water compartment dilutes the salt concentration in the other compartment over time, and reduces the driving force of diffusion and osmosis (Kingsbury et al., 2018). The permeability of diffusion was established by the amount transferred by the membrane of a substance over a surface unit per unit of time. Thus, the permeability coefficients of membranes for salt diffusion can be determined by the formula given in Equation 1 of the experimental salt permeability obtained from the reference for a steady flow of liquid from the salt compartment to the distilled water compartment (Alekseeva et al., 2012).

$$
P_{S}=\frac{C_{2} \cdot V_{2} \cdot X}{\left(C_{1}-C_{2}\right) \cdot S \cdot t}
$$

where: $P S$ is $\mathrm{NaCl}$ diffusion permeability, $\left(\mathrm{m}^{2} / \mathrm{s}\right) ; C_{1}$ and $C_{2}$ are the total concentration of the components in salt solution and water, respectively $\left(\mathrm{mol} / \mathrm{m}^{3}\right) ; V_{2}$ is the volume of water at the end of the experiment $\left(\mathrm{m}^{3}\right) ; S$ is membrane operating area $\left(\mathrm{m}^{2}\right) ; X$ is the membrane thickness (m); $t$ is the test time (s).

The water flow from compartment filled with distilled water to compartment filled with $\mathrm{NaCl}$ solution is measured by the change in the amount of solution in horizontal capillaries over a given period. The osmotic permeability coefficient is determined by Equation 2 (Alekseeva et al., 2012).

$$
P_{w}=\frac{n_{w} \cdot X}{\left(C_{1}-C_{2}\right) \cdot S \cdot t}
$$


where: $P_{w}$ is distilled water osmatic permeability $\left(\mathrm{m}^{2} / \mathrm{s}\right) ; n_{w}$ is the moles of distilled water transferred (mol). It was measured from volume change in the distilled water compartment.

\section{Experimental Setup}

Before the operational process, MK-40 is cleaned with a carbon tetrachloride solution and wait 15 minutes for the membrane to dry, and then cleaned with an ethanol solution and wait 15 minutes for the membrane to dry. After that, the membranes are placed in a saturated solution of sodium chloride $(\mathrm{NaCl})$ for 24 hours and then placed in distilled water for 24 hours. Subsequently, MK-40 is placed in $(0.1 \mathrm{M})$ of $\mathrm{NaOH}$ solution for 24 hours and then placed in distilled water for 24 hours. Then, the MK-40 is placed in $(0.1$ $\mathrm{M})$ of $\mathrm{HCl}$ solution for 24 hours and then placed in distilled water until a neutral reaction. In the operational process, membrane coupons were fixed in the cell for 24 hours before operation to achieve pseudo-stable osmosis and diffusion.

In this experiment, a two-compartment cell was employed to study the permeability characteristics of $\mathrm{MK}-40$, as shown in Figure 1. In order to do so, $\mathrm{NaCl}$ as a salt solution and distilled water as solvent were used. The volumes of the left half-cell contained $\mathrm{NaCl}$ solution, and the right half-cell contained distilled water were $550 \mathrm{~cm}^{3}$ each. The membrane area was $31.4 \mathrm{~cm}^{2}$, and its thickness was $1 \mathrm{~mm}$. The cell was connected to the

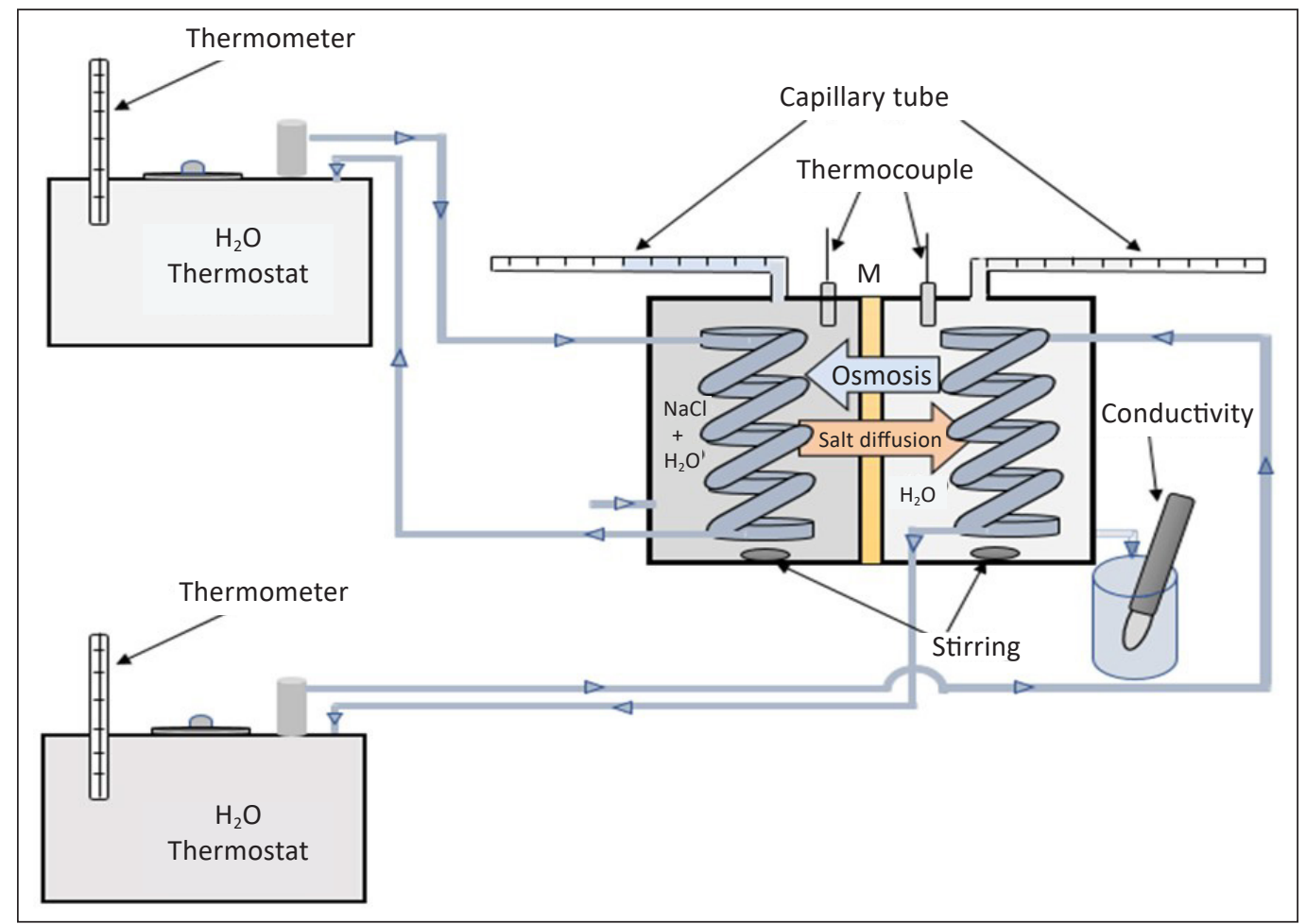

Figure 1. Schematic experiment diagram of two-compartment cell 
thermostat box to maintain the cell temperature, and each compartment was connected to the thermocouple to measure temperature of the compartments. Different concentrations of $\mathrm{NaCl}(0.1,0.5$ and $1 \mathrm{M})$ and temperatures of distilled water $\left(25\right.$ and $\left.50^{\circ} \mathrm{C}\right)$ were selected to monitor diffusion and osmotic rates.

The two compartments were immediately filled with new solutions and distilled water. Once an operation began, the $\mathrm{NaCl}$ solution chamber and the distilled water chamber were stirred at $300 \mathrm{rpm}$ with magnetic stir bars. The salt diffusion coefficient and osmotic water coefficient were determined due to water moving into the high concentrated compartment due to the osmosis process, while the salt diffused through the membrane into the distilled water compartment due to a concentration gradient. Each compartment of the cell was sealed and connected to a capillary tube, which made it possible to measure the volume change in the compartment with high accuracy. Then, the conductivity of distilled water compartment was measured over 15 min transition periods for each experiment, and the calibration curve using $\mathrm{NaCl}$ standard solutions converted these conductivity measurements to salt concentration. Finally, the salt diffusion coefficient and distilled water osmatic coefficient were measured using Equations 1 and 2, respectively.

\section{RESULTS AND DISCUSSION}

There are many properties of ion exchange membrane that influence salt diffusions, such as membrane chemical structure and water content. Diffusion of salt and osmosis of solvent are key factors that lead to variations in permeability of commercial MK-40 membrane. This study used, $\mathrm{NaCl}$ as a salt and water as a solvent, and the results were discussed below.

\section{Diffusion Permeability of $\mathrm{NaCl}$}

Diffusion permeability coefficients of $\mathrm{NaCl}$ were calculated using Equation 1. Figure 2 presents the $\mathrm{NaCl}$ diffusion permeability coefficients at two distilled water temperatures (25 and $\left.50^{\circ} \mathrm{C}\right), \mathrm{NaCl}$ concentrations $(0.1,0.5$ and $1 \mathrm{M})$, and $20 \mathrm{~min}$ transition periods. Over operational time of 20 to $100 \mathrm{~min}$, when $\mathrm{NaCl}$ concentration was $0.1,0.5$ and 1 $\mathrm{M}$, Figure 2 (a) showed that $\mathrm{NaCl}$ diffusion permeability coefficient decreased from $2.31 \times 10^{-9}$ to $1.76 \times 10^{-9}\left(\mathrm{~m}^{2} / \mathrm{s}\right), 2.19 \times 10^{-9}$ to $1.62 \times 10^{-9}\left(\mathrm{~m}^{2} / \mathrm{s}\right)$ and $1.97 \times 10^{-9}$ to $1.53 \times 10^{-9}$ $\left(\mathrm{m}^{2} / \mathrm{s}\right)$ at temperatures of $25^{\circ} \mathrm{C}$, respectively. During the same operational period, at $\mathrm{NaCl}$ concentration of $0.1,0.5$ and $1 \mathrm{M}$, Figure 2 (b) illustrated that $\mathrm{NaCl}$ diffusion permeability coefficient declined from $7.37 \times 10^{-9}$ to $3.88 \times 10^{-9}\left(\mathrm{~m}^{2} / \mathrm{s}\right), 6.41 \times 10^{-9}$ to $3.54 \times 10^{-9}\left(\mathrm{~m}^{2} / \mathrm{s}\right)$ and $5.41 \times 10^{-9}$ to $3.15 \times 10^{-9}\left(\mathrm{~m}^{2} / \mathrm{s}\right)$, when temperature was $50^{\circ} \mathrm{C}$, respectively.

Drop-in $\mathrm{NaCl}$ diffusion permeability coefficients could be due to water flux from diluted water compartment to salt solution compartment, lowering the driving force for diffusion and osmosis (Kingsbury et al., 2018). After about $60 \mathrm{~min}$ of operational time, $\mathrm{NaCl}$ diffusion permeability coefficients were approximately constant for both temperatures 


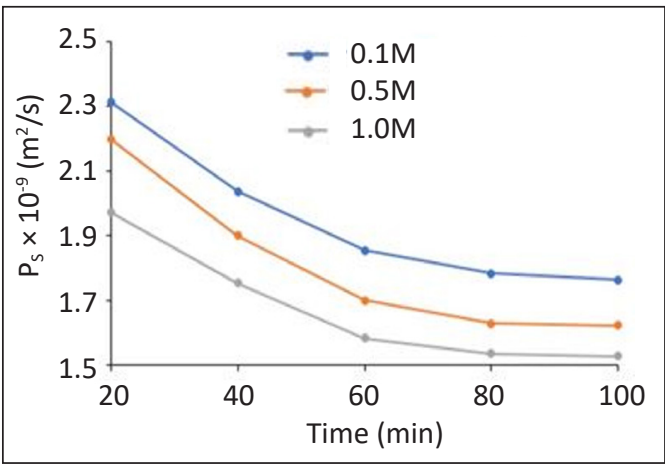

(a)

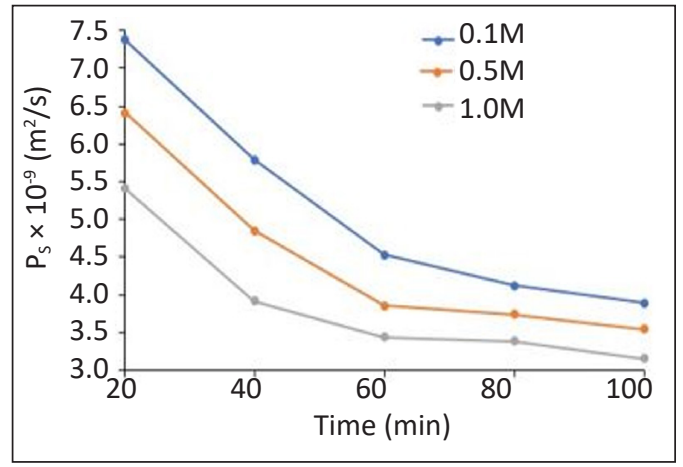

(b)

Figure 2. $\mathrm{NaCl}$ diffusion permeability coefficients at two different distilled water temperatures, (a) $25^{\circ} \mathrm{C}$ and (b) $50^{\circ} \mathrm{C}$, using different $\mathrm{NaCl}$ concentrations, $0.1,0.5$, and $1 \mathrm{M}$, over 100 min operational time

because of concentration polarisation resulting from increased salt concentration in the boundary layer near the surface of the membrane (Melnikov et al., 2018). It prevents salt penetration through the membrane, explaining why the diffusion permeability was approximately constant after 60 minutes of operation.

MK-40 membrane showed low permeability to $\mathrm{NaCl}$, which results in minimising energy losses in the electrodialysis process. In comparison, Kamcev et al. (2018) investigated $\mathrm{NaCl}$ diffusion permeability coefficients of cation exchange membrane (CR61), using a high $\mathrm{NaCl}$ concentration of $1 \mathrm{M}$. They found that diffusion permeability coefficients were $1.7 \times 10^{-10}\left(\mathrm{~m}^{2} / \mathrm{s}\right)$.

Figures 2(a) and 2(b) both revealed that a higher temperature of $50^{\circ} \mathrm{C}$ has led to higher permeability than $25^{\circ} \mathrm{C}$. It could be because the higher temperature can enhance the permeation rate and accelerate the ions transport across membranes (Luo et al., 2010). To date, there are very few studies reporting the diffusion permeability of membranes at high temperatures. It can be noticed that higher salt concentration has significantly decreased the diffusion permeability coefficients of MK-40 membrane. Over an operational period of 20-100 min, when the $\mathrm{NaCl}$ concentration increased from $0.1 \mathrm{M}$ to $1 \mathrm{M}, \mathrm{NaCl}$ diffusion permeability coefficients of the MK-40 membrane fell by about $24 \%-22 \%$ and $47 \%-41 \%$, for the temperature of 25 and $50^{\circ} \mathrm{C}$, respectively. It indicates that the MK-40 membrane is uncharged due to decreased polymer's water content as salt concentration increases. In contrast to charged membranes, when salt concentration increases, the salt diffusion permeability coefficients increase (Geise et al., 2013).

Tanaka (2011) investigated that when the temperature of ion exchange membranes such as Selemion CMR/ASR and Neocepta CIMS/ACS3 increased from $25^{\circ} \mathrm{C}$ to $50^{\circ} \mathrm{C}$, the overall hydraulic permeability was increased from $\left(1.116 \times 10^{2}\right.$ to $\left.1.937 \times 10^{2}\right) \mathrm{cm}^{4}$. eq. ${ }^{-1} \cdot \mathrm{s}^{-1}$ and $\left(1.254 \times 10^{2}\right.$ to $\left.1.835 \times 10^{2}\right) \mathrm{cm}^{4}$.eq. ${ }^{-1} \cdot \mathrm{s}^{-1}$. It confirms that when using a higher operating temperature, the membrane's diffusion permeability will increase, which will 
lead to a decrease in the efficiency of the MK-40 membrane. According to Gatapova et al. (2020), an ion-exchange membrane (MK-40) diffusion permeability coefficient for a $\mathrm{NaCl}$ solution under thermostatic and thermodynamic conditions has been investigated. They found a significant difference in diffusion coefficient values when operating at the same temperature compared to the temperatures difference on both sides.

\section{Osmatic Permeability of Solvent}

Various experiments were performed to investigate the transport of solvents in ionexchange membranes (Alekseeva et al., 2012, Kingsbury et al., 2019). In this study, the water transport occurs as free water (osmosis), not as bound water (electro-osmosis). The osmatic permeability coefficients of distilled water were calculated using Equation 2. Over an operational period of 20-100 min, Figure 3 showed the osmatic permeability coefficients of distilled water at two distilled water temperatures $\left(25\right.$ and $\left.50^{\circ} \mathrm{C}\right), \mathrm{NaCl}$ concentrations $(0.1,0.5$ and $1 \mathrm{M})$, and $20 \mathrm{~min}$ transition periods. Over operational time of 20 to $100 \mathrm{~min}$, when $\mathrm{NaCl}$ concentration was $0.1,0.5$ and $1 \mathrm{M}$, Figure 3 (a) showed that $\mathrm{NaCl}$ osmotic permeability coefficient decreased from $3.57 \times 10^{-9}$ to $1.58 \times 10^{-9}\left(\mathrm{~m}^{2} / \mathrm{s}\right), 2.09 \times 10^{-9}$ to $0.8338 \times 10^{-9}\left(\mathrm{~m}^{2} / \mathrm{s}\right)$ and $0.948 \times 10^{-9}$ to $0.2 \times 10^{-9}\left(\mathrm{~m}^{2} / \mathrm{s}\right)$ at temperatures of $25^{\circ} \mathrm{C}$, respectively. On the other hand, under the same operating conditions, at $\mathrm{NaCl}$ concentration of $0.1,0.5$ and $1 \mathrm{M}$, Figure 3 (b) illustrated that the $\mathrm{NaCl}$ diffusion permeability coefficient declined from and $43.8 \times 10^{-9}$ to $21.13 \times 10^{-9}\left(\mathrm{~m}^{2} / \mathrm{s}\right), 29.66 \times 10^{-9}$ to $9.75 \times 10^{-9}\left(\mathrm{~m}^{2} / \mathrm{s}\right)$ and $10.53 \times 10^{-9}$ to $3.73 \times 10^{-9}\left(\mathrm{~m}^{2} / \mathrm{s}\right)$, when the temperature was $50^{\circ} \mathrm{C}$, respectively.

Decreasing osmotic permeability coefficients could be due to high salt concentration gradients lead to increase water flux from diluted water compartment to salt solution compartment due to osmosis (Kingsbury et al., 2018). Therefore, it is concluded that salt concentration's gradients should be essentially low to minimise the distilled water's flow

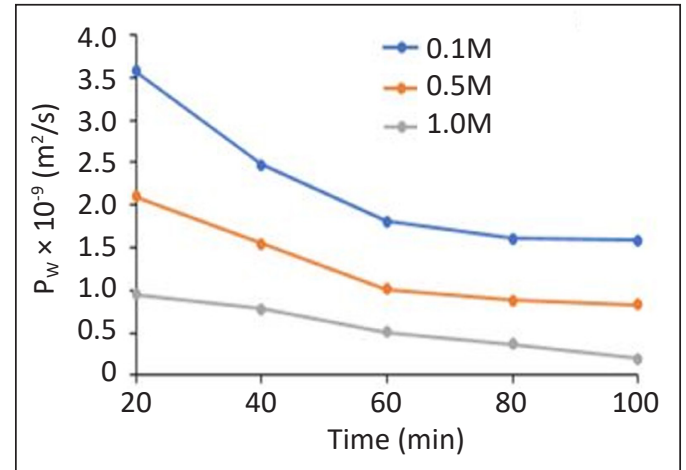

(a)

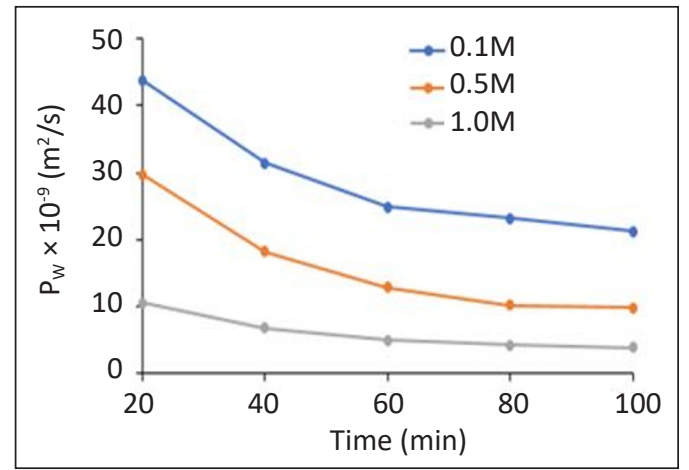

(b)

Figure 3. Water permeability coefficients at two different distilled water temperatures, (a) $25^{\circ} \mathrm{C}$ and (b) $50^{\circ} \mathrm{C}$, using different $\mathrm{NaCl}$ concentrations, $0.1,0.5$, and $1 \mathrm{M}$, over 100 min operational time 
due to osmosis, which increases the osmotic permeability coefficient. Furthermore, it could be due to concentration polarisation resulting from increased $\mathrm{NaCl}$ concentration in the membrane boundary layer (Melnikov et al., 2018). Osmotic permeability coefficients were also approximately constant for both temperatures $\left(25^{\circ} \mathrm{C}\right.$ and $\left.50^{\circ} \mathrm{C}\right)$ after 60 minutes of operation.

A few studies have examined the influence of temperature on osmotic performance. Zhao and Zou (2011) studied the effect of temperature on membrane performance during osmosis desalination, and their results confirmed that the flux increases with increasing temperature. Kingsbury et al. (2018) investigated the water permeability coefficient of CEM (Nafion N115) using $4 \mathrm{M}$ of $\mathrm{NaCl}$ solution; the results were $1.13 \times 10^{-10}\left(\mathrm{~m}^{2} / \mathrm{s}\right)$. It can be concluded that the CEM membrane type (MK-40) has a low permeability to water, which results in minimising energy losses. It is noted that an increase in the overall $\mathrm{NaCl}$ solution concentration and an increase in distilled water temperature significantly affect osmotic permeability coefficient. Eventually, the findings showed that higher permeability of water was correlated with higher permeability of salt.

\section{CONCLUSION}

The diffusion and osmotic permeability have been successfully studied to characterize the heterogeneous cation exchange membrane (MK-40) using different concentrations of $\mathrm{NaCl}$ solution and distilled water temperatures. Salt concentration and water temperature were among the most important parameters affecting the diffusion and osmotic permeability of MK-40. The uncharged MK-40 membrane had low permeability to salt, which results in minimising energy losses. Nevertheless, the MK-40 membrane revealed that as the salt concentration of the external solution decreases, the diffusion permeability of the membrane increases. Since osmotic pressure is a linear function of solution concentration, osmotic water transfer increases linearly with increasing salt concentration. On the other hand, the temperature and flux time affected the diffusion and osmosis permeability of the membrane. For example, at a distilled water temperature of $50^{\circ} \mathrm{C}$, the osmotic permeability coefficient of MK-40 was significantly higher than at $25^{\circ} \mathrm{C}$.

\section{ACKNOWLEDGEMENT}

Authors wish to thank Tambov State Technical University-Russia for facilitating the laboratory work and Northern Technical University-Iraq for the fund.

\section{REFERENCES}

Alekseeva, N. V., Arkhipov, A. I., \& Borisov, P. A. (2012). Study of diffusive and osmotic permeability of MK-40 and MA-40 electrodialysis membranes in two-component solutions of Copper, Zinc, Nickel and Sodium salts. Вестник ТГТУ, 18(4), 923-927. 
Andreeva, M. A., Loza, N. V., Pis'menskaya, N. D., Dammak, L., \& Larchet, C. (2020). Influence of surface modification of MK-40 membrane with polyaniline on scale formation under electrodialysis. Membranes, 10(7), 1-14. https://doi.org/10.3390/membranes10070145

Chaabouni, A., Guesmi, F., Louati, I., Hannachi, C., \& Hamrouni, B. (2015). Temperature effect on ion exchange equilibrium between CMX membrane and electrolytes solutions. Journal of Water Reuse and Desalination, 5(4), 535-541. https://doi.org/10.2166/wrd.2015.008

Chehayeb, K. M., \& Lienhard, J. H. (2019). On the electrical operation of batch electrodialysis for reduced energy consumption. Environmental Science: Water Research \& Technology, 5(6), 1172-1182. https:// doi.org/10.1039/C9EW00097F

Gatapova, N. T., Dzhubari, M. K., \& Alekseeva, N. V. (2020). A study of diffusion permissibility of MK-40 membrane in thermodynamic conditions. Вестник ТГТУ, 26(4), 619-628.

Geise, G. M., Freeman, B. D., \& Paul, D. R. (2013). Sodium chloride diffusion in sulfonated polymers for membrane applications. Journal of Membrane Science, 427, 186-196. https://doi.org/10.1016/j. memsci.2012.09.029

Geise, G. M., Paul, D. R., \& Freeman, B. D. (2014a). Fundamental water and salt transport properties of polymeric materials. Progress in Polymer Science, 39(1), 1-42. https://doi.org/10.1016/j.progpolymsci.2013.07.001

Geise, G. M., Cassady, H. J., Paul, D. R., Logan, B. E., \& Hickner, M. A. (2014b). Specific ion effects on membrane potential and the permselectivity of ion exchange membranes. Physical Chemistry Chemical Physics, 16(39), 21673-21681. https://doi.org/10.1039/C4CP03076A

Gubari, M. Q., Zwain, H. M., Alekseeva, N. V. \& Baziyani, G. I. (2021). Features of feed concentration and temperature effects on membranes operation in electrodialysis systems - A review. Journal of Physics: Conference Series, 1973(1), 012178.

Gubari, M. Q., Zwain, H. M., Al-Zahiwat, M. M., \& Alekseeva, N. V. (2021). Characteristics of the MK40 and MA-40 membranes for industrial wastewater treatment - A review. Ecological Engineering \& Environmental Technology, 22(1), 39-50. https://doi.org/10.12912/27197050/132095

Guesmi, F., Hannachi, C., \& Hamrouni, B. (2010). Effect of temperature on ion exchange equilibrium between AMX membrane and binary systems of $\mathrm{Cl}^{-}, \mathrm{NO}^{-}{ }_{3}$ and $\mathrm{SO}^{2-}$ ions. Desalination and Water Treatment, 23(1-3), 32-38. https://doi.org/10.5004/dwt.2010.1837

Kamcev, J., Paul, D. R., Manning, G. S., \& Freeman, B. D. (2018). Ion diffusion coefficients in ion exchange membranes: Significance of counterion condensation. Macromolecules, 51(15), 5519-5529. https://doi. org/10.1021/acs.macromol.8b00645

Karimi, L., \& Ghassemi, A. (2016). How operational parameters and membrane characteristics affect the performance of electrodialysis reversal desalination systems: The state of the art. Journal of Membrane Science and Research, 2(3), 111-117. https://doi.org/10.22079/JMSR.2016.20309

Kingsbury, R. S., Bruning, K., Zhu, S., Flotron, S., Miller, C. T., \& Coronell, O. (2019). Influence of water uptake, charge, manning parameter, and contact angle on water and salt transport in commercial ion exchange membranes. Industrial \& Engineering Chemistry Research, 58(40), 18663-18674. https://doi. org/10.1021/acs.iecr.9b04113 
Kingsbury, R. S., Zhu, S., Flotron, S., \& Coronell, O. (2018). Microstructure determines water and salt permeation in commercial ion-exchange membranes. ACS Applied Materials \& Interfaces, 10(46), 3974539756. https://doi.org/10.1021/acsami.8b14494

Luo, J., Wu, C., Wu, Y., \& Xu, T. (2010). Diffusion dialysis of hydrochloride acid at different temperatures using PPO-SiO $\mathrm{Si}_{2}$ hybrid anion exchange membranes. Journal of Membrane Science, 347(1-2), 240-249. https://doi.org/10.1016/j.memsci.2009.10.029

Melnikov, S., Kolot, D., Nosova, E., \& Zabolotskiy, V. (2018). Peculiarities of transport-structural parameters of ion-exchange membranes in solutions containing anions of carboxylic acids. Journal of Membrane Science, 557, 1-12. https://doi.org/10.1016/j.memsci.2018.04.017

Mikhaylin, S., \& Bazinet, L. (2016). Fouling on ion-exchange membranes: Classification, characterization and strategies of prevention and control. Advances in Colloid and Interface Science, 229, 34-56. https:// doi.org/10.1016/j.cis.2015.12.006

Nikonenko, V., Nebavsky, A., Mareev, S., Kovalenko, A., Urtenov, M., \& Pourcelly, G. (2019). Modelling of ion transport in electromembrane systems: Impacts of membrane bulk and surface heterogeneity. Applied Sciences, 9(1), Article 25. https://doi.org/10.3390/app9010025

Pismenskaya, N., Melnik, N., Nevakshenova, E., Nebavskaya, K., \& Nikonenko, V. (2012). Enhancing ion transfer in overlimiting electrodialysis of dilute solutions by modifying the surface of heterogeneous ion-exchange membranes. International Journal of Chemical Engineering, 2012, Article 528290. https:// doi.org/10.1155/2012/528290

Sarapulova, V., Shkorkina, I., Mareev, S., Pismenskaya, N., Kononenko, N., Larchet, C., Dammak, L., \& Nikonenko, V. (2019). Transport characteristics of Fujifilm ion-exchange membranes as compared to homogeneous membranes AMX and CMX and to heterogeneous membranes MK-40 and MA-41. Membranes, 9(7), Article 84. https://doi.org/10.3390/membranes9070084

Tanaka, Y. (2011). Ion-exchange membrane electrodialysis for saline water desalination and its application to seawater concentration. Industrial \& Engineering Chemistry Research, 50(12), 7494-7503. https://doi. org/10.1021/ie102386d

Vasil'eva, V. I., Akberova, E. M., Zhiltsova, A. V., Chernykh, E. I., Sirota, E. A., \& Agapov, B. L. (2013). SEM diagnostics of the surface of MK-40 and MA-40 heterogeneous ion-exchange membranes in the swollen state after thermal treatment. Journal of Surface Investigation. X-ray, Synchrotron and Neutron Techniques, 7, 833-840. https://doi.org/10.1134/S1027451013050194

Zhao, S., \& Zou, L. (2011). Effects of working temperature on separation performance, membrane scaling and cleaning in forward osmosis desalination. Desalination, 278(1-3), 157-164. https://doi.org/10.1016/j. desal.2011.05.018 
